Ann. Biol. anim. Bioch. Biophys, I969, 9 (4), 463-473.

\title{
RESISTANCE OF TRITIUM ACTIVITY IN ADENINE-2,8-T LABELLED RABBIT SPERM
}

\author{
V. KOPEČNÝ* and I. TREBICHAVSKÝ*** \\ with technical assistance of Marianna LAngerovi, Jana Novotna and V. PeCH* \\ * Labovatory of Animal Genetics, Libechov, \\ **Institute of Microbiology, Laboratory of Electron Microscopy, Prague, \\ Czechoslovak Acadcmy of Sciences
}

\section{SUMMARY}

Rabbit spermatozoa were labelled in vivo by injecting a male whith $6 \mathrm{mCi}$ of 2,8-T-adenine. On day 49 after injection, a suspension of spermatozoa from caudae epididymidis and ductus deferentes in saline was prepared.

Sperm samples were stored frozen at $-5^{\circ} \mathrm{C}$, exposed to autolysis for ro days at $+37^{\circ} \mathrm{C}$, and smeared. Smears from freshly obtained sperm were hydrolyzed with $\mathrm{HCl}$ IN or extracted with TCA (table I).

All smears were coated with Kodak stripping film AR.ro and the autoradiographs obtained were evaluated quantitatively. No marked difference was detected between fresh and frozen + autolyzed sperm in grain number/sperm head. Graphical and statistical analyses confirmed the non-significance of differences. Accuracy of the autoradiographic method used is supposed to be sufficient to exclude considerable loss of activity from the sperm heads. (Standard deviation of repeated determination of mean grain count in the same slide amounts approximately to 5 per cent. On the contrary, complete loss of activity was detected in hydrolyzed and extracted smears.

Presence of some activity in the autolysed sperm medium in a substance utilizable by bacteria was revealed in a few labelled bacterial colonies.

Ultrastructure of the sperm nucleus was well preserved even after autolysis and did not show any sign of major deoxyribonucleoprotein loss.

\section{INTRODUCTION}

Working in normal artificial insemination conditions, SALISBURY et al. (I96I) found a considerable decrease of Feulgen stainability in the heads of bull spermatozoa during storage. These observations were interpreted by those authors as resulting from a direct loss of DNA amounting to 30 per cent in 5 days. 
By means of DNA extraction and its subsequent determination when storing bull spermatozoa at room temperature for 2I days SEGINA and NoRMAN (I964) found that 6I per cent DNA was lost.

ANAND ( 1967 ) also detected an average DNA loss of 15.4 per cent, by determination after extraction, after 24 hours storage of boar spermatozoa. This basic concept of DNA loss from sperm heads was supported by several other investigators working mainly with cytospectrophotometry after Feulgen staining (e. g. HANADA et al., I965 ; PAUFLER and FOOTE, I967).

The results obtained by BouTERs et al. (r967) and GLEDHILL et al. (I966) are contrary to these findings. These authors compared the DNA content in mammalian spermatozoa during their maturation in the male tract with the values obtained by microspectrophotometry in UV light after Feulgen staining and microspectrophotometry. They agreed that DNA content in the spermatozoa remained unchanged during their maturation in the male genital tract, but that Feulgen stainability decreased. GLEDHILL (Ig66) offered further evidence of DNA constancy during epididymal maturation of bull spermatozoa by means of microinterferometric determination of dry mass and microplanimetric determination of the optical area.

A new methodological approach for reinvestigation of this problem was introduced by KOEFOED-JOHNSEN et al. (I967, I968). They labelled one of the DNA pyrimidine bases in vivo (thymine in rabbit spermatozoa), and evaluated autoradiographically the relative radioactivity level in fresh and in stored and autolyzed sperm. No decrease of activity due to "leakage " could be detected even after 240 hours autolysis at $+37^{\circ} \mathrm{C}$.

The aim of the present work was to study the stability of purine bases in the sperm under extreme storage conditions, also using autoradiography. The difference in resistance between purine and pyrimidine bases towards mild hydrolysis may substantiate the concept of selective loss from the DNA molecule during aging of spermatozoa, namely if this difference is much more pronounced in spermatozoa than in other somatic cells (SANDRITTER et al., I964, BöHm et al. I968).

Another aim of this study was to investigate the ultrastructure of spermatozoa after extreme storage conditions.

\section{MATERIAL AND METHODS}

\section{Production of labelled spermatozoa}

An outbred male rabbit was injected intraperitoneally with $6 \mathrm{mCi}$ adenine-2,8-T-(Institut fir angewandte Isotopenforschung, Berlin, $D D R$, spec. activity I.I $5 \mathrm{mCi} / \mathrm{mg}$ ). The rabbit was killed on day 49 after injection, both caudae epididymidis and ductus deferentes were removed and the spermatozoa retrieved, diluted with saline, and thoroughly mixed. A relatively clean sperm suspension was thus obtained without the admixtures which are usually present in rabbit ejaculates.

Table I demonstrates the treatment of spermatozoa.

\section{Autoradiographic procedure for light microscopy}

Sperm smears from all treatments were fixed with methyl alcohol, fat extracted by an alcoholether mixture and coated in two series with Kodak stripping film AR.ro according to ScHMID and CARnES (I965). Autoradiographs were stained with Harris hæmatoxyline-eosine. Great care was taken to keep the procedure identical for all smears from different treatments in each series. 


\section{Evaluation of autoradiographs under light microscope}

I ooo spermatozoa from each treatment were evaluated and their association with silver grains noted. The mean number of grains per sperm was calculated from these data.

The reliability of grain/sperm head determination had been tested before on very similar material. The standard deviation for repeated determination of grain number per sperm in the same sample amounts to an average of about 5 per cent for the same observer (KOEFOED-JOHNSEN el al., 1967, 1968).

To determine the background level we used slides with smears of non-labelled spermatozoa prepared simultaneously with the experimental smears. According to these results, spermatozoa with 4 or more silver grains were considered as labelled $(P=99.9$ per cent $)$. Evaluations were carried out independently by two persons, V. P. and J. N.

\section{TABLE I}

Treatment of spermatozoa

Traitement des spermatozoides

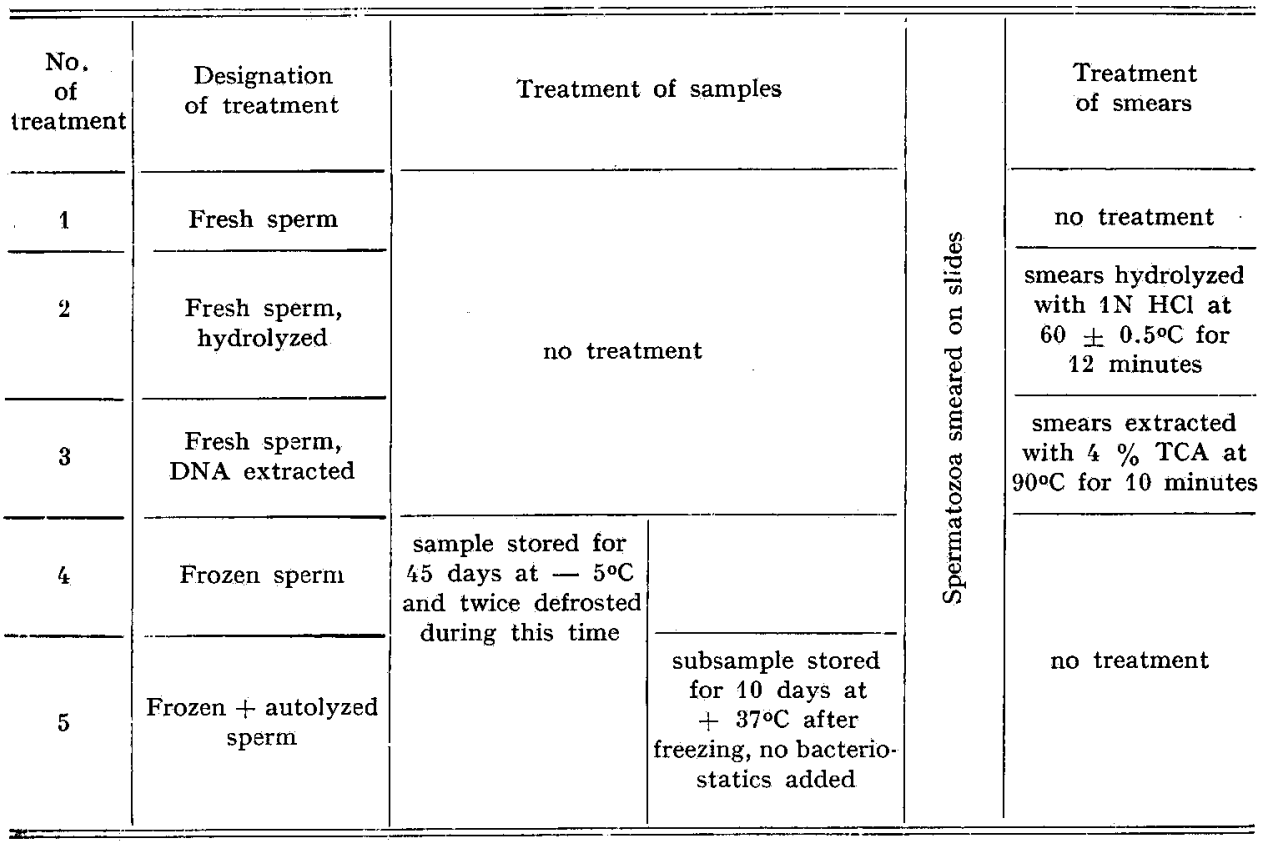

\section{Electron microscopy and autoradiography}

The suspension of frozen + autolyzed sperm was fixed according to KELLENBERGER (I958) and embedded in Vestopal. Sections were prepared on an ultramicrotome LKB and contrasted with $\mathbf{5}$ per cent uranyl acetate in water for examination of ultrastructure. Some of the non-contrasted slides were coated with Ilford liquid emulsion $\mathrm{L}_{4}$ and exposed for 9o days. Autoradiographs were then developed in Microdol at $19.5^{\circ} \mathrm{C}$ for 2 minutes, and examined without contrasting. A Tesla electronmicroscope (prototype UPT Brno, Czechoslovakia) was used. 


\section{RESULTS}

Iabelling of spermatozoa is shown in fig. I-3.

Results from relative quantitative evaluation of autoradiographs of fresh, frozen, and frozen + autolyzed sperm, fresh hydrolyzed sperm and sperm after DNA extraction are given in table 2. Data from control slides with non-labelled spermatozoa are also shown.

Labelled spermatozoa from different treatments were plotted to histographs according to series and observer (fig. 8).

Relative quantitative evaluation of autoradiographs from fresh, frozen and frozen + autolyzed spermatozoa did not lead to the detection of differences in the level of ${ }^{3} \mathrm{H}$ activity. The mean grain number/sperm head, histographs of distribution of labelled spermatozoa, and analysis of data by means of the $\chi^{2}$ test showed that the differences between treatments are not significant.

However, hydrolysis of spermatozoa in $\mathrm{HCl} \mathrm{IN}$, and extraction by hot TCA have reduced activity down to the background level.

In autoradiographs from autolyzed sperm, a few multilayered colonies of bacteria were detected which were highly labelled (fig. 7). In monolayers and in individual bacteria, labelling was not significantly above the background level (fig.6). Labelling in individual bacteria could be proved only with high resolution autoradiography under electron microscope (fig. 8).

The examination of the ultrastructure in autolyzed sperm showed that after loss of the acrosome, the other structures of the sperm head were extremely resistant (fig. 2, 3, 4, 5). Our material did not permit any conclusions regarding eventual detailed changes.

\section{DISCUSSION}

Labelled adenine is utilized in vivo mainly for the synthesis of nucleic acids, both purines, adenine and guanine in DNA being labelled (DAvidson I960). It is further possible to detect the label in ejaculated spermatozoa (SIRL,IN, EDWARDS, I955; FOOTE, KOEFOED-JOHNSEN, I959, KOPEČNY, I967). In our experiments, the specific labelling of purines was proved by complete removal of activity after hydrolysis with $\mathrm{HCl} \mathrm{IN}$, at $60^{\circ} \mathrm{C}$ for I2 minutes.

Smears from mammalian spermatozoa are an ideal substrate for semi-quantitative autoradiography of tritium. The spermatozoon lies with its flat side on the microscopic slide so that the specimen is about $0.5 \mu$ thick, the cytoplasmic part being negligible. The area taken $u p$ by the sperm head is nearly constant for one ejaculate (BEATTY, SHARMA, I960). In our experiments, special attention was given to creating suitable conditions for identical autoradiographic handling of the slides in order to ensure reliable observation of the relative quantity of activity in individual smears. We used Kodak stripping film AR. Io which ensures an even layer of emulsion on the slides. Conditions within each series were identical, especially with respect 

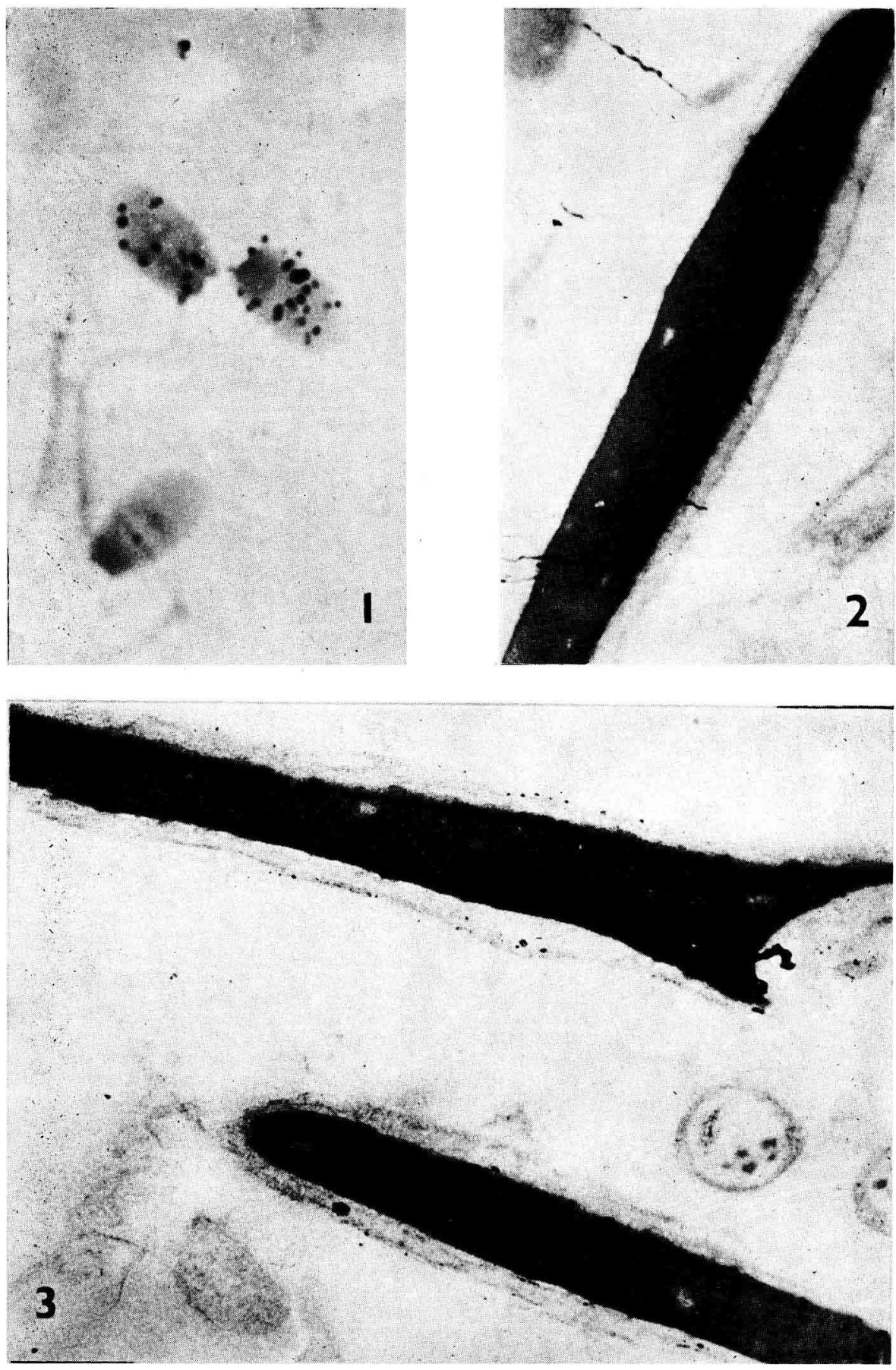

FIG. I to 3. - Autoradiographs of adenine-2,8-T labelled rabbit spermatozoa after ro days storage at $+37^{\circ} \mathrm{C}$.

In light microscope (fig. I, magnified approx. 2,000 times) the level of activity in relation to nontreated sperm could be measured by grain counting. In high-resolution autoradiographs (fig. 2 anc! 3 , magn. approx. 30,00o times) see the localization of activity in the nucleus and well preserved head structures.

FIG. I à 3. - Autoradiographies des spermatozoüdes de Lapin marquès à l'adénine-2,8-T, après to jours de conservation à $+37^{\circ} \mathrm{C}$

Fig. I $(\times 2000)$ : on peut mesurer l'activité par rapport au sperme non traité en comptant les grains. Fig. $2-3(\times 30000):$ remarquer la localisation de l'activite dans le noyau et les bien maintenu structures de la tête. 
V. KOPEČNÝ, I. TREBICHAVSKÝ

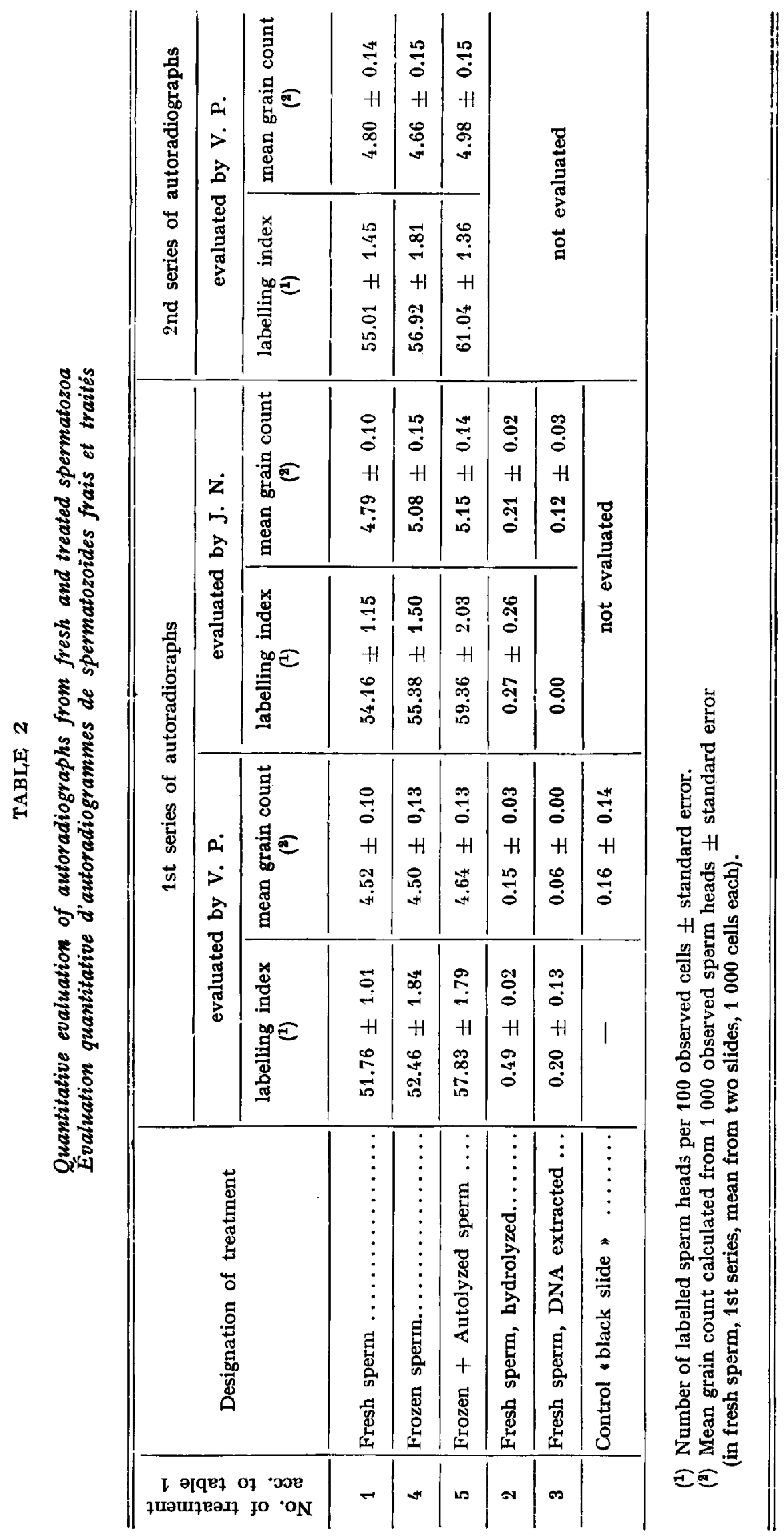





FIG. 4 and 5. - Ultrastructure of sperm heads (treated as in fig. $\mathrm{x}-3$. )

Magnified approx. 20,000 times, fig. 4 ; and 30,000 times in fig. 5. Contrasted with uranylacetate for demonstration of head menbranes. In fig. 4 bottom : bacteria present.

FIG. 4 et 5. - Ultrastructure de la tête, des spermatozoïdes, traités de même manière (comme FIG. I-3)

contrastée avec de l'uranylacétate pour mettre en évidence les membranes de la tête.

Fig. $4 \times 20000$

Fig. $5 \times 30000$ 

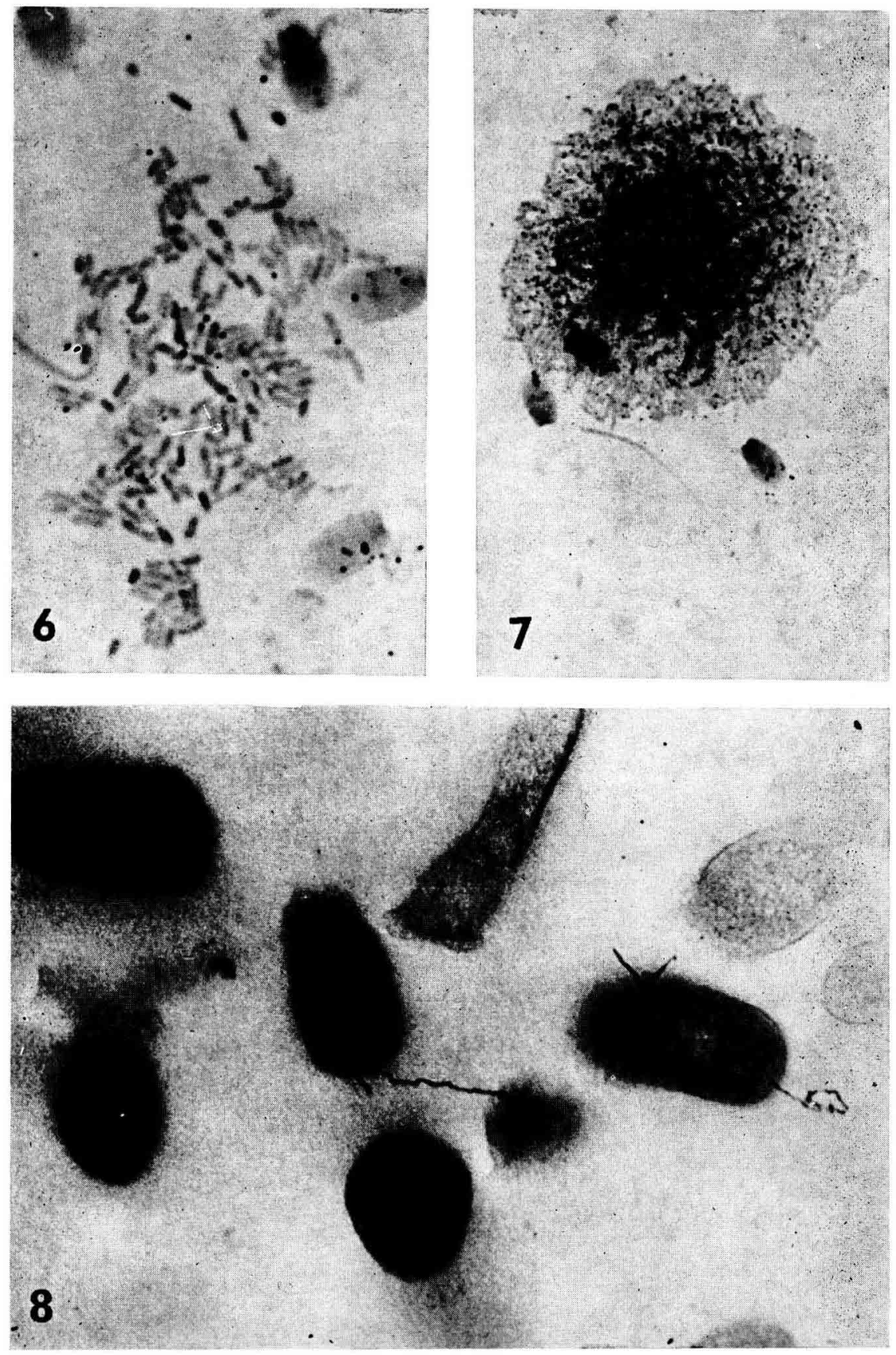

FIG. 6 to 8. - Utilization of labelled material by bacteria

In monolayer of bacteria the level of activity is almost undetectable (fig. 6, magn. approx. I,50o times). Over multilayered colonies the labelling is quite distinct (Fig. 7, magn, approx. 1,000 times). Even high resolution autoradiographs revealed labelling in some bacteria (Fig. 8, magn. approx. 30,000 times).

FIG. 6 aे 8. - Utilisation du materiel marqué par les bactéries

En couche monocellulaire l'activité est indécelable (fig. $6 \times 1500$ )

En couche multicellulaire le marquage est visible (fig. $7 \times$ I ooo)

Fig. $8(\times 30000)$ : l'autoradiographie révèle le marquage de quelques bactéries 


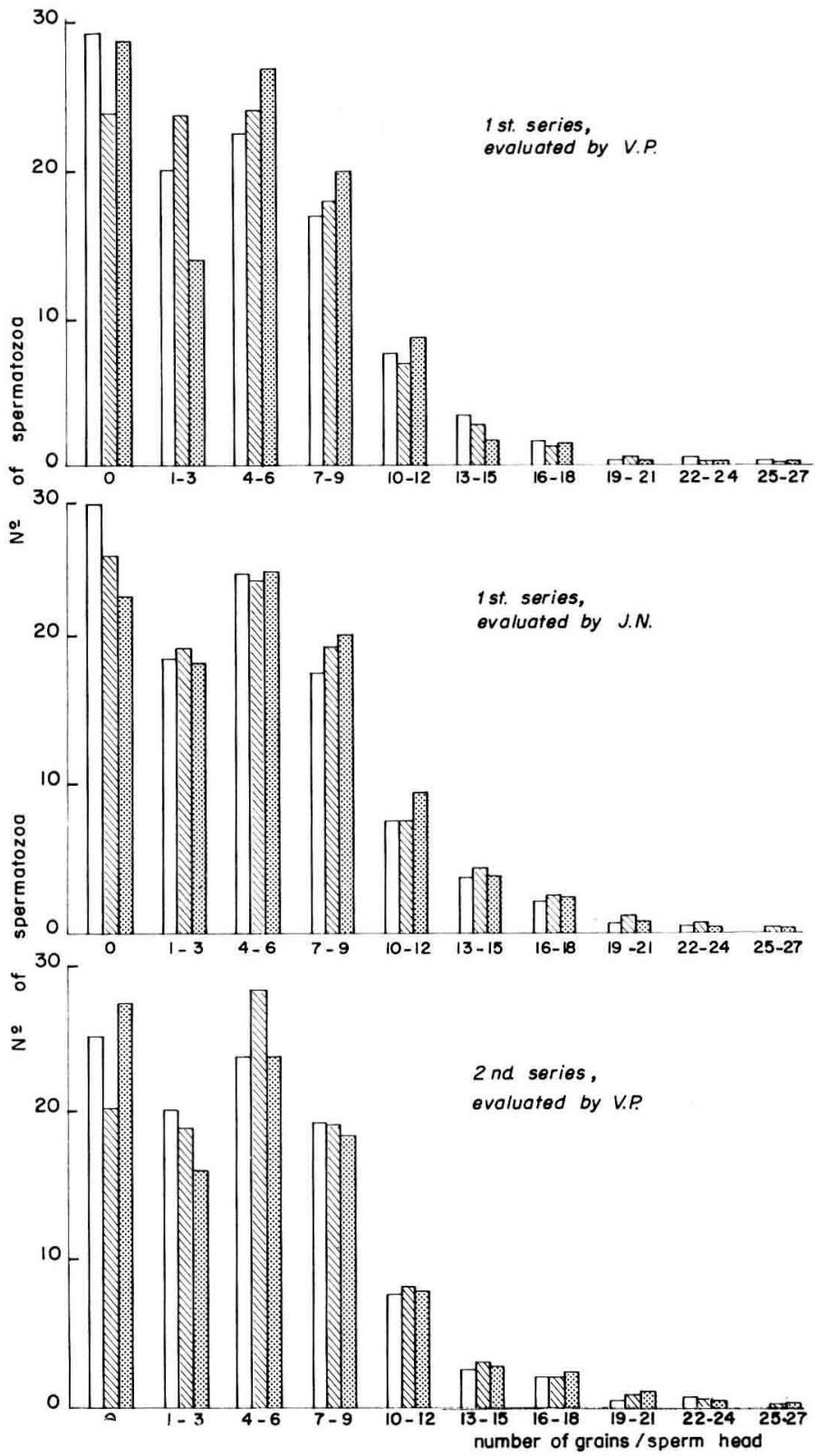

$\begin{array}{lll}\text { fresh sperm } & \text { sperme frais } \\ \text { frozen sperm } & \text { sperme congelé } \\ \text { frozen + autolysed sperm } & \text { sperme congelé autolysé }\end{array}$

FIG. 9. Mean distribution of labelled spermatozoa in autoradiographs of fresh and treated spermatozoa.

Labelled spermatozoa ( $P=99.9$ ) with 4 and more grains/head.

No significant differences between fresh and treated spermatozoa acc. to $\chi^{2}$ test were detected.

FIG. 9. - Distribution moyenne des spermatozoïdes marqués sur des autoradiographies de spermatozoides frais et traites

Les spermatozoïdes marqués $(P=99,9)$ ont au moins 4 grains par tête

Pas de différence significative entre sperme frais et traité (test $\mathrm{X}^{2}$ ) 
to developing and staining. However, the adjustment of relatively low grain number/ cell was chosen intentionally. In tritium radiography saturation phenomena in the photographic emulsion must be considered which greatly influence the linearity of response just after the formation of only a few grains (LEVI, I964).

After storage under such extreme conditions as ro days autolysis at $+37^{\circ} \mathrm{C}$ after previous freezing, the accuracy of our method (average standard deviation of repeated mean grain count estimate $=5$ per cent for the same person) seems sufficient to eliminate a greater loss of DNA during current storage conditions. Our findings are in agreement with the results of KRAMER (I968), and ACKERMANN and SoDMoRIAH (I968) who did not detect DNA loss in spermatozoa after freezing, and TöRö and PòsALAKY (I959) who noted that even after two weeks autolysis there was no change in the Feulgen stainability of spermatozoa.

Our results together with the findings of KOEFOED-JoHNSEN et al. (1967, I968) on thymine stability in spermatozoal DNA during autolysis, allow us to presume that there is no difference in the binding resistance of DNA bases during current storage conditions of spermatozoa, and that this resistance is considerably high.

The well preserved morphological structures of the sperm nucleus and the postacrosomal cap do not infer a greater loss of sperm nucleoprotein.

The small amount of labelled substrate in the medium, utilizable by bacteria, may be interpreted as loss of labelled substance of spermatozoa which escaped evaluation because it lies below the sensitivity level of our method. Another interpretation, however, may be based on the fact that after application of tritiated adenine, numerous body cells are labelled; their labelled disintegration products may remain in the body a long time after the original precursor has been completely removed. In our experiment the time interval between application of labelled adenine and isolation of spermatozoa amounts to 49 days. Labelled disintegration products may be reutilized, and incorporated into the spermatozoa outside DNA, or be present in body fluids. In any case, it is evident that the level of labelled substrate in the medium was very low, as detection was possible only in multilayered bacterial colonies. There were only a few labelled colonies detected which did not allow histochemical evaluation of labelling specificity.

Reçu pour publication en juin 1969.

\section{RÉSUMÉ}

RESISTANCE ESTIMEE PAR L'ACTIVITE DU TRITIUM DU SPERME DE LAPIN MARQUE A L'ADENINE-2,8-T

Les spermatozoïdes de lapin ont été marqués in vivo par une injection de $6 \mathrm{mCi}$ de 2,8 -Tadénine, administrée à un mâle. Le $49^{\mathrm{e}}$ jour après l'injection, une suspension dans du sérum physiologique de spermatozoïdes provenant de la queue de l'épididyme et des canaux déférents a été préparée.

Les échantillons du sperme ont été stockés congelés à $-5^{\circ} \mathrm{C}$, puis exposés à l'autolyse pendant ro jours à $+37^{\circ} \mathrm{C}$ et étalés sur les lames. Les frottis de sperme fraîchement obtenu ont été hydrolysés avec $\mathrm{HCl}$ I $\mathrm{N}$, ou extraits TCA (tabl. I).

Tous les frottis ont été revêtus d'émulsion pelliculable Kodak AR. ro et les autoradiogrammes obtenus ont été évalués quantitativement. 
Il n'y avait pas de différences significatives entre le sperme frais ou congelé et autolysé quant aux nombres de grains/tête de spermatozoïdes. Une analyse graphique et statistique a confirmé la non signifiance des différences. La précision de la méthode autoradiographique utilisée semble suffisante pour éliminer une perte d'activité considérable des têtes de spermatozoīdes (la déviation standard des numérations de grains répétées sur la même lame était d'environ $5 \mathrm{p}$. Ioo). Une perte d'activité totale, au contraire, a été observée sur les frottis hydrolysés et extraits.

Au sein du milieu constitué par le sperme autolysé, la présence d'une certaine activité dans une substance utilisable par les bactéries a été détectée dans quelques colonies bactériennes.

L'ultrastructure du noyau de spermatozoïdes a été bien préservée, même après autolyse, et n'a montré aucun signe de perte importante de désoxyribonucléoprotéine.

\section{RÉFÉRENCES BIBI,IOGRAPHIQUES}

Ackermann D.-R., Sod-Moriah U.-A., 1968. DNA content of human spermatozoa after storage at low temperaure. J. Reprod. Fert., 17, I-7.

ANAND A.-S., Hoekstra W.-G., First N.-L., I967. Effect of aging of boar spermatozoa on cellular loss of DNA. J. anim. Sci., 26, I7I-173.

Beatty R.-A., Sharma K.-N., I960. Genetics of gametes. III. Strain differences in spermatozoa from eight inbred strains of mice. Proc. Roy. Soc. Edinburgh, B., 68. 25-53.

Böhm N., Sprenger E., Schlüter G., Sandritter W., I968. Proportionalitätsfehler bei derFeulgen Hydrolyse. Histochemie, 15, I94-203.

Bouters R., Esnault C., Ortavant R., Salisbury G.-W., r967. Comparison of DNA revealed by Feulgen and by ultra-violet light in rabbit spermatozoa after storage in the male efferent ducts. Nature, 218, $18 \mathrm{I}-182$.

Davidson J.-N., 1960. The biochemistry of the nucleic acids, 4 th edition, 197-230, Methuen, London.

Foote R.-H., Koefoed-Johnsen H.-H., 1959. The use of adenine 8-C ${ }^{14}$ for studying spermatogenesis in the rabbit. J.anim. Sci., 18, I553.

GiedHill B.-L., I 966 . Studies on the DNA content, dry mass and optical area of bull spermatozoal heads during epididymal maturation. Acta Veter. Scand., 7, $\mathbf{1}_{3}^{1} \mathrm{I}_{4} 2$.

Gledhill B.-L., Gledhili, M.-P., Rigler R., Ringertz N.-R., I966. Changes in the deoxyribonucleoprotein during spermiogenesis in the bull. Exp. Cell Res., 41, 652-665.

Hanada A., Hrroe K., Tomizuka T., 1965. DNA content in bull spermatozoa during storage in yolk citrate diluent at $4^{\circ} \mathrm{C}$. Jap. J. anim. Reprod., 10, 103-109.

Kellenberger E., Ryter A., Sechaud I., I958. Electron microscope study of DNA-containing plasm. II. J. Biophys. Biochem. Cytol., 4, 67 $1-678$.

Konfond-Johnsen H.-H., FUlKA J., Kopec̉nÝ V., Ig67. Investigations sur la teneur de ADN dans les spermatozoïdes du Lapin pendant le storage in vitro (en danois). Aarsberetning Inst. f. Sterilitetsforskn. Copenhagen., 10, 9-x8.

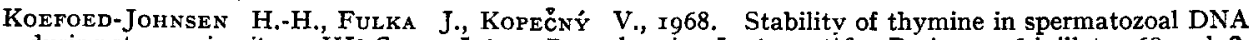
during storage in vitro. 'VI Ie Congr. Intern. Reprod. anim. Insém. artific., Paris, 22-26 juillet 1968, vol. 2, I263-I266.

KOPEC̊NY் V., I967. Résultats obtenus jusqu'à présent en marquage quantitatif de spermatozoïdes par l'adénine et la thymidine ${ }^{2} \mathrm{H}$. (en tchèque). Živöc. víyr., 12, 813-822.

KRAMER M.-F., I 968 . DNA content of spermatozoa in fertile and infertile bulls, and errors in its determination. Ann. Biol, anim. Bioch. Biophys., 8, 2I7-224.

LEVi H., r964. The interpretation of autoradiographs, especially when using tritium as a tracer. Scand. J. Hamat., 1, 138-149.

PAUfler- S.-K., FOOTE R.-H., I967. Influence of light on nuclear size and deoxyribonucleic acid content of stored bovine spermatozoa. J. Dairy Sci., 50, 1457-1480.

Salisbury G.-W., De la Torre L., Birge W.-J., Lodge J.-R., 196I. Decrease in nuclear Feulgenpositive material (DNA) upon aging in vitro storage of bovine spermatozoa. J. Biophys. Bioch. Cytol., 10, 353-359.

SANDRITTER W., Bosselmann K., Rakow L., JobST K, I964. Untersuchungen zur Feulgenreaktion. Die Langzeithydrolyse bei verschiedenen Zelltypen. Biochim. Biophys. Acta, 81, 645-647.

Schmid W., Carnes J,-D., r965. Autoradiography of human chromosomes, in : Human Chromosome Methodology, ed. Yunis J.-J., Academic Press, 9 I-1 Io.

Segina M.-R., Norman C., I964. Age related changes in the DNA of bovine sperm. Proc. V. Int. Congr. Anim. Reprod., Trento, vol. 4, 276-280.

Sirlin J.-L., Edwards R.-G., I965. The labelling of mouse sperm by adenine-8-C-r4. Exp. Cell Res., 9, 596-599.

Törö L., Pósalaky Z., 1959. Histochemische Untersuchung der Spermiogenese Acta Histochem. 8, 393-405. 